\title{
Fertility in young men and women after treatment for lymphoma: a study of a population
}

\author{
DJ KING, MA RATCLIFFE, AA DAWSON, B BENNETT, JE MACGREGOR, * \\ AI KLOPPER† \\ From the Departments of Medicine, *Pathology, and †Obstetrics, University of Aberdeen, Aberdeen, Scotland
}

SUMMARY All young patients in the Grampian area attending the lymphoma review clinic who had received first line treatment for Hodgkin's disease and had attained complete remission without subsequent relapse were studied between 1980 and 1983 . Chemotherapy with MVPP (mustine, vinblastine, procarbazine, and prednisolone) had more severe effects on the fertility of men than that of women; younger women and those taking oral contraceptives were more likely to retain fertility than those over 30 or not taking the pill at the time of chemotherapy, but these two effects could not be differentiated. Premature menopause was common after treatment with MVPP. Mantle radiotherapy had no discernible effect on gonadal function.

In recent years intensive radiotherapy and chemotherapy have strikingly increased survival in patients with Hodgkin's disease. This advance has been gained at a price, and attention is now focused on the long term side effects of treatment. Of these, secondary acute non-lymphoblastic leukaemia and non-Hodgkin's lymphoma are the most serious. Less immediately threatening, but of major importance to patients, most of whom are young, are impaired fertility and gonadal function, which can have major physical and psychological consequences.

Several studies have indicated that fertility is changed after treatment for Hodgkin's disease. ${ }^{1-11}$ Most of these studies have been carried out at major reference centres, and thus a degree of patient selection has operated. Treatment has not always been standardised, with some patients receiving multiple treatments. In the Grampian area all patients with lymphoma from a population base of 520000 were diagnosed, staged, and treated by a single unit, and follow up was at a common outpatient clinic. Thus an entire group from one geographic and demographic area was studied, and patients were not subject to any form of selection before treatment other than that of having Hodgkin's disease. We report on the fertility of all young men and women treated with radiotherapy or chemotherapy from an entire population who were studied up to 12 years after treatment.

Accepted for publication 10 July 1985

\section{Patients and methods}

We studied patients attending for treatment or follow up during the years 1980-3. Patients with Hodgkin's disease aged under 40 at the time of treatment and in first remission at the time of observation were included. For the purposes of this report we included only those whose treatment was standard-that is, those who received either mantle or inverted $\mathrm{Y}$ radiotherapy-or who had completed six to nine cycles of MVPP treatment (mustine, vinblastine, procarbazine, and prednisolone) with or without mantle radiotherapy.

Any patient whose treatment varied from the above in any way was excluded, with the exception of one young man mentioned below, whose MVPP treatment was completed over a longer period than usual. A few young patients who received chemotherapy other than MVPP for non-Hodgkin's lymphoma were included separately as detailed below.

In men the number of children fathered before and after treatment was recorded. All men were asked to supply samples of semen for analysis; not all complied with this request, but in all serum concentrations of follicle stimulating and luteinising hormones and testosterone were measured serially when they attended for review.

The women had pretreatment and post treatment pregnancies recorded, and follicle stimulating hormone, luteinising hormone, oestradiol-17, and progesterone concentrations were measured often. 
They were regarded as having an ovulatory cycle and as being potentially fertile if the progesterone concentration rose above $20 \mathrm{nmol} / \mathrm{l}(6.3 \mathrm{ng} / \mathrm{l})$ in any cycle. ${ }^{12}$ Repeated hormone assays were also used to establish whether patients were menopausal, and they were identified as such if they did not menstruate and their assays showed follicle stimulating hormone and luteinising hormone concentrations $>20$ $\mathrm{mIU} / \mathrm{ml}$. The age at treatment, the interval between treatment, and the most remote point of study were also recorded for all patients.

The steroids were measured by standard radioimmunoassay techniques, ${ }^{13-15}$ using highly specific antisera that did not cross react a great deal with other related steroids in blood. Luteinising hormone and follicle stimulating hormone were also measured by radioimmunoassay using the kits supplied by Serono. This is a double antibody method using polyethylene glycol as a precipitating agent, and the standards are calibrated in terms of first International Reference Preparation 68/40. The lower limit of sensitivity for both proteins is 2 $\mathrm{mIU} / \mathrm{ml}$. The range of luteinising hormone for normal men is $2-10 \mathrm{mIU} / \mathrm{ml}$ and for menopausal women $20-70 \mathrm{mIU} / \mathrm{ml}$. With the exception of the midcycle peak, the values in the mentrual cycle do not exceed $16 \mathrm{mIU} / \mathrm{ml}$. For follicle stimulating hormone the range in men is $1-8 \mathrm{mIU} / \mathrm{ml}$, and the range during the menstrual cycle does not exceed 10 $\mathrm{mIU} / \mathrm{ml}$ except at the midcycle peak. The range for menopausal women is $20-100 \mathrm{mIU} / \mathrm{ml}$. The normal range for plasma testosterone in men is 14-42 $\mathrm{nmol} / \mathrm{l}(4 \cdot 0-12 \cdot 1 \mathrm{ng} / \mathrm{ml})$.

\section{STATISTICAL ANALYSIS}

In men the differences in follicle stimulating hormone and luteinising hormone between those treated by mantle radiotherapy or by MVPP chemotherapy were assessed by the unpaired $t$ test.
In women retention of fertility was compared with age at treatment by an unpaired $t$ test and with the use of the oral contraceptive pill by the $\chi^{2}$ test with Yates's correction.

\section{Results}

MEN

Of men who received mantle radiotherapy, nine had previously fathered children (Table 1). Eight subsequently fathered children or had normal sperm counts; the seven others declined to submit semen samples but all had concentrations of follicle stimulating hormone, luteinising hormone, and testosterone within the normal range when studied. Of four who received inverted $Y$ radiotherapy, two had previously fathered children, and three were subsequently shown to be infertile on the basis of complete azoospermia. This group showed a rise in follicle stimulating hormone concentrations after treatment but no reduction of plasma testosterone.

Of 20 men who completed six to nine cycles of treatment with MVPP, 14 provided semen samples for analysis; all showed complete azoospermia, which was maintained up to 10 years after treatment. One other man in this group fathered two children after chemotherapy: this man completed his chemotherapy with MVPP but was a defaulter, and thus his treatment was delivered over a considerably longer period of time than is standard; when studied four years later his follicle stimulating hormone value was $9.2 \mathrm{mIU} / \mathrm{ml}$. Compared with those treated by mantle radiotherapy, this group showed a striking and significant rise in mean serum follicle stimulating hormone values $(p<0.001)$, which was sustained many years after treatment. In a similar comparison mean luteinising hormone concentration was also significantly increased $(p<0.05)$; the

Table 1 Effect of treatment on fertility in men

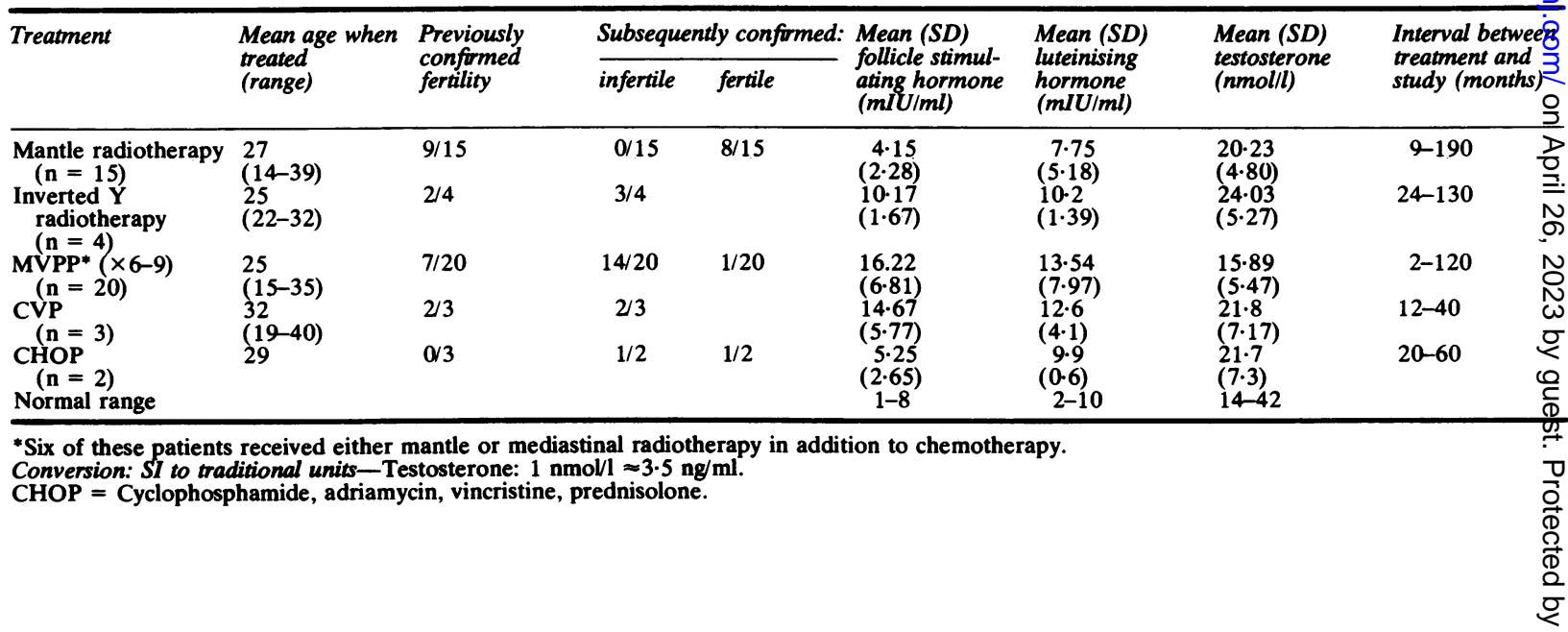


mean testosterone value was slightly lower in the group treated with MVPP but remained within the normal range.

Fewer men were studied before, during, and after treatment. Table 2 shows that mean follicle stimulating hormone values were normal in all groups before treatment and were unchanged after mantle radiotherapy but were converted to high values after both inverted $Y$ radiotherapy and treatment with MVPP. Those undergoing treatment with MVPP were also studied (on average after three cycles of MVPP) and showed conversion to high follicle stimulating hormone values.

\section{WOMEN}

Table 3 shows that mantle radiotherapy had no discernible effect on fertility in young women. Ten of 11 women who had undergone mantle treatment either achieved pregnancy or showed clear hormonal evidence of ovulation in the years after treatment. The three women who received inverted $Y$ treatment showed no evidence of fertility thereaf- ter. In contrast to the findings in the young men, however, almost half of the women who received a full course of treatment with MVPP remained fertile; half of these became pregnant while the rest showed hormonal evidence of ovulation. A small group $(n=5)$ used oral contraceptives during the time in which they received MVPP, and four of these remained fertile. Of the larger group who did not use oral contraceptives, only $30 \%$ remained fertile, but this apparent difference between the groups was not significant $(p>0.05)$.

Table 4 compares all women who remained fertile after treatment with MVPP with those who became infertile. Evidently, not only did a higher proportion of those remaining fertile use oral contraception during treatment but also those remaining fertile came to treatment at a considerably earlier age than did those subsequently found to be infertile; the difference in mean age of those retaining and those losing fertility was not, however, significant ( $p>$ 0.05 ).

Table 5 gives details of women were menopausal

Table 2 Mean hormone values in men

\begin{tabular}{|c|c|c|c|c|}
\hline Type of treatment & $\begin{array}{l}\text { Before } \\
\text { treatment }\end{array}$ & $\begin{array}{l}\text { During } \\
\text { treatment }\end{array}$ & $\begin{array}{l}\text { After } \\
\text { treatment }\end{array}$ & $\begin{array}{l}\text { Normal } \\
\text { range }\end{array}$ \\
\hline \multicolumn{5}{|l|}{ Mantle radiotherapy $(n=5)$} \\
\hline $\begin{array}{l}\text { Follicle stimulating hormone }(\mathrm{mIU} / \mathrm{ml}) \\
\text { Luteinising hormone }(\mathrm{mIU} / \mathrm{ml}) \\
\text { Testosterone }(\mathrm{nmol} / \mathrm{l})\end{array}$ & $\begin{array}{r}6 \cdot 0 \\
8 \cdot 5 \\
25 \cdot 1\end{array}$ & & $\begin{array}{r}6 \cdot 0 \\
7 \cdot 5 \\
25 \cdot 0\end{array}$ & $\begin{array}{l}2-10 \\
2-9 \\
14-42\end{array}$ \\
\hline \multicolumn{5}{|l|}{ Inverted Y radiotherapy $(n=1)$} \\
\hline $\begin{array}{l}\text { Follicle stimulating hormone }(\mathrm{mIU} / \mathrm{ml}) \\
\text { Luteinising hormone }(\mathrm{mIU} / \mathrm{ml})\end{array}$ & $\begin{array}{r}3 \cdot 8 \\
5 \cdot 6 \\
37.7\end{array}$ & & $\begin{array}{r}12 \cdot 2 \\
8 \cdot 4\end{array}$ & $\begin{array}{l}2-10 \\
2 \cdot 9\end{array}$ \\
\hline \multicolumn{5}{|l|}{ MVPP $(n=4)$} \\
\hline $\begin{array}{l}\text { Follicle stimulating hormone }(\mathrm{mIU} / \mathrm{ml}) \\
\text { Luteinising hormone }(\mathrm{mIU} / \mathrm{ml}) \\
\text { Testosterone (nmoll) }\end{array}$ & $\begin{array}{r}4 \cdot 1 \\
10 \cdot 2 \\
13 \cdot 2\end{array}$ & $\begin{array}{r}15 \cdot 1 \\
9 \cdot 8 \\
9 \cdot 2\end{array}$ & $\begin{array}{r}21.4 \\
9.9 \\
20.6\end{array}$ & $\begin{array}{l}2-10 \\
2-9 \\
14 \cdot 42\end{array}$ \\
\hline
\end{tabular}

Conversion: SI to traditional units-Testosterone: $1 \mathrm{nmol} / \mathrm{l} \approx 3.5 \mathrm{ng} / \mathrm{ml}$.

Table 3 Effect of treatment on fertility in women

\begin{tabular}{|c|c|c|c|c|c|c|}
\hline \multirow[t]{2}{*}{ Treatment } & \multirow{2}{*}{$\begin{array}{l}\text { Mean age } \\
\text { at treatment } \\
\text { (range) }\end{array}$} & \multirow{2}{*}{$\begin{array}{l}\text { Previously confurmed } \\
\text { fertility }\end{array}$} & \multirow{2}{*}{$\begin{array}{l}\text { Oral contraceptives } \\
\text { used during treatment }\end{array}$} & \multicolumn{2}{|c|}{ Subsequently confurmed: } & \multirow{2}{*}{$\begin{array}{l}\text { Interval to study } \\
\text { (Months) }\end{array}$} \\
\hline & & & & Infertile & Fertile & \\
\hline \multirow{6}{*}{$\begin{array}{l}\text { Mantle radiotherapy } \\
(n=11) \\
\text { Inverted Y radio- } \\
\text { therapy }(n=3) \\
\text { MVPP* }(\times 6-9) \\
(n=18) \\
\text { MVPP and oral } \\
\text { contraceptives } \\
(n=5) \\
\text { MVPP without oral } \\
\text { contraceptives } \\
(n=13) \\
\text { CHOP } \\
(n=2)\end{array}$} & \multirow{4}{*}{$\begin{array}{l}26 \\
(19-34) \\
30 \\
(22-41) \\
27 \\
(17-39) \\
24 \\
(18-32)\end{array}$} & $6 / 11$ & $5 / 11$ & $1 / 11$ & \multirow{2}{*}{$\begin{array}{l}10 / 11 \\
7 \text { pregnant } \\
0 / 3\end{array}$} & $6-80$ \\
\hline & & $3 / 3$ & $0 / 3$ & $3 / 3$ & & $6-140$ \\
\hline & & $10 / 18$ & $5 / 18$ & $10 / 18$ & \multirow{2}{*}{$\begin{array}{l}8 / 18 \\
4 \text { pregnant } \\
4 / 5 \\
2 \text { pregnant }\end{array}$} & $6-120$ \\
\hline & & $2 / 5$ & $5 / 5$ & $1 / 5$ & & $6-80$ \\
\hline & $\begin{array}{l}27 \\
(17-39)\end{array}$ & $8 / 13$ & $0 / 13$ & $9 / 13$ & $\begin{array}{l}4 / 13 \\
2 \text { pregnant }\end{array}$ & $6-120$ \\
\hline & 24,35 & $1 / 2$ & $0 / 2$ & $0 / 2$ & $2 / 2$ & $6-9$ \\
\hline
\end{tabular}

*Six of these patients had mantle or mediastinal radiotherapy in addition to chemotherapy.

CHOP = Cyclophosphamide, adriamycin, vincristine, prednisolone. 
Table 4 Comparison of women remaining fertile with those becoming infertile after chemotherapy

\begin{tabular}{|c|c|c|c|c|}
\hline & $\begin{array}{l}\text { Mean age at } \\
\text { treatment } \\
\text { (range) }\end{array}$ & $\begin{array}{l}\text { Previous } \\
\text { fertility }\end{array}$ & $\begin{array}{l}\text { Oral contraceptives } \\
\text { used during treatment }\end{array}$ & $\begin{array}{l}\text { Interval to study } \\
\text { (months) }\end{array}$ \\
\hline $\begin{array}{l}\text { Remaining fertile } \\
(n=8)\end{array}$ & \multirow{2}{*}{$\begin{array}{l}23 \\
(17-32) \\
29 \\
(23-39)\end{array}$} & $2 / 8$ & $4 / 8$ & $6-114$ \\
\hline $\begin{array}{l}\text { Became infertile } \\
\quad(n=10)\end{array}$ & & $8 / 10$ & $1 / 10$ & $6-120$ \\
\hline
\end{tabular}

Table 5 Menopause induced by treatment

\begin{tabular}{|c|c|c|c|c|}
\hline Case no & Treatment & $\begin{array}{l}\text { Age at } \\
\text { menopause }\end{array}$ & $\begin{array}{l}\text { Interval between treatment } \\
\text { and menopause (years) }\end{array}$ & Symptoms \\
\hline $\begin{array}{r}1 \\
2 \\
3 \\
4 \\
5 \\
6 \\
7 \\
8 \\
9 \\
10 \\
11 \\
12 \\
13\end{array}$ & $\begin{array}{l}\text { MVPP } \times 6 \dagger \\
\text { MVPP } \times 9 \dagger \\
\text { MVPP } \times 6 \dagger \\
\text { MVPP } \times 9 \dagger \\
\text { MVPP } \times 60^{\dagger} \\
\text { MVPP } \times 6 \\
\text { MVPP } \times 9 \\
\text { MVPP } \times 6 \dagger \\
\text { MVPP } \times 8 \\
\text { MVPP } \times 9 \\
\text { MVPP } \times 9 \\
\text { MVPP } \times 9 \dagger \\
\text { MOPP } \times 12\end{array}$ & $\begin{array}{l}32^{*} \\
33^{*} \\
40^{*} \\
31^{*} \\
32^{*} \\
30 \\
32 \\
41 \\
33 \\
43 \\
35 \\
30 \\
36\end{array}$ & $\begin{array}{r}2 \\
1 \\
11 \\
7 \\
1 \\
8 \\
6 \\
0 \\
1 \\
4 \\
4 \\
4 \\
4\end{array}$ & $\begin{array}{l}\dagger \\
\dagger \\
\dagger\end{array}$ \\
\hline
\end{tabular}

*Patients for whom the date of onset of the menopause was defined precisely by serial hormone assays. $\dagger$ Patients who received mantle radiotherapy in addition to chemotherapy.

MOPP = Mustine, vincristine, procarbazine, prednisolone.

after chemotherapy as indicated by appreciably raised serum concentrations of follicle stimulating hormone and luteinising hormone. In the first five patients the time of onset of the menopause was defined precisely by observing the conversion of their hormone profile from one in which follicle stimulating hormone and luteinising hormone values were low to one in which these values were consistently high. The other women were found to have high follicle stimulating hormone and luteinising hormone values when they were first studied; thus the interval between treatment and menopause in these women was, of necessity, overestimated. With this reservation in mind, the interval between treatment and menopause in those who received MVPP under the age of 30 was seven years while that in patients receiving MVPP over the age of 30 was two years. About half the women identified biochemically as menopausal complained spontaneously of characteristic menopausal symptoms.

A few men and women received other forms of chemotherapy for non-Hodgkin's lymphoma. Of three men treated with CVP (cyclophosphamide, vincristine, prednisolone), two were shown to be completely azoospermic after treatment, in one case up to $\mathbf{4 0}$ months later (Table 1). This group also showed the appreciable rise in follicle stimulating hormone after treatment seen in patients receiving MVPP. Two men received six cycles of CHOP (cyc- lophosphamide, adriamycin, vincristine, prednisolone). One man continued to produce normal quantities of viable sperm consistently after treatment; the other was judged infertile, producing sperm in reduced quantity. Neither of these men showed the striking rise in follicle stimulating hormone seen in the other groups. Two women received treatment with $\mathrm{CHOP}$, one for six cycles and the other for four cycles followed by two cycles of ChlVP (chlorambucil, vincristine, and prednisolone); both showed evidence of ovulatory activity thereafter.

\section{Discussion}

Treatment of Hodgkin's disease now secures a long term cure for many young patients. A precise identification of the incidence and reversibility of long term side effects in patients treated in routine clinics is therefore essential. Several detailed studies have identified impaired fertility both in men and women after treatment, particularly chemotherapy ${ }^{1-11}$ (although some men are subfertile before treatment $\left.{ }^{6}{ }^{7}\right)$. The incidence of impaired fertility has varied like that of recovery of gonada function. This study was undertaken with the aim of establishing the incidence, time of onset, and duration of infertility and impaired production of sex hormones caused by standard radiotherapy or a 
single course of first line chemotherapy for newly diagnosed Hodgkin's disease in all young unselected patients with the disease.

In such a group mantle radiotherapy had no discernible effect on the fertility of young men and women, but, as might be expected, inverted $Y$ radiotherapy regularly produced sustained infertility in both sexes. Treatment with MVPP given over the usual time produced azoospermia in all men studied, and this persisted for up to 10 years with no recovery. it was accompanied by a sustained and striking increase in follicle stimulating hormone and a less pronounced increase in luteinising hormone and normal testosterone values, suggesting specific destruction of spermatogenesis and partial but incomplete impairment of interstitial cell function. By contrast, treatment with MVPP in women had a less profound effect on fertility, about half the women showing evidence of fertility after treatment. Those remaining fertile when studied were, on average, younger at the time of treatment and more likely to have used oral contraceptives during treatment. These differences between the fertile and infertile groups were not significant, although the trends support those seen in other studies. ${ }^{1617}$ About half the women receiving MVPP became menopausal biochemically, and half of these had characteristic menopausal symptoms. Not surprisingly, those receiving treatment before the age of 30 had a longer interval between treatment and menopause than those treated over the age of 30 . Probably, those who showed evidence of fertility after treatment and were not menopausal at the time of study will all, ultimately, have a premature menopause.

Treatment of non-Hodgkin's lymphoma with CVP caused azoospermia, with the characteristic rise of follicle stimulating hormone in a few men. Curiously, treatment of non-Hodgkin's lymphoma with CHOP both in men and in women produced less profound changes in fertility during the period of observation, but numbers were too small to allow conclusions to be drawn about this form of treatment.

This simple study indicates the incidence or impaired gonadal function, which is likely to be of major importance to young patients undergoing treatment for Hodgkin's disease when this is delivered in a general hospital setting and when all the patient population at risk is studied. It provides practical figures of the incidence of the side effects of treatment, which have proved invaluable to us in counselling patients at our clinic. Such data need to be made available for widespread use, and $l_{i}$-rer systematic studies on similarly unselected patients are required.

\section{References}

' Van Thiel DH, Sherins RJ, Myers GH, De Vita VT. Evidence for a specific seminiferous tubular factor affecting folliclestimulating hormone secretion in men. J Clin Invest 1972;51:1009-19.

${ }^{2}$ Sherins RJ, De Vita VT. Effect of drug treatment for lymphoma on male reproductive capacity; studies of men in remission after therapy. Ann Intern Med 1973;79:216-20.

${ }^{3}$ Sherins RJ, Olweny CLM, Ziegler JL. Gynecomastia and gonadal dysfunction in adolescent boys treated with combination chemotherapy for Hodgkin's disease. N Engl J Med 1978; 299: 12-6.

${ }^{4}$ Schilsky RL, Sherins RJ, Hubbard SM, Wesley MN, Young RC, De Vita VT. Long term follow up of ovarian function in women treated with MOPP chemotherapy for Hodgkin's disease. Am J Med 1981;71:552-6.

s Chapman RM, Sutcliffe SB, Rees LH, Edwards CRW, Malpas JS. Cyclical combination chemotherapy and gonadal function; retrospective study in males. Lancet 1979;i:285-9.

- Chapman RM, Sutcliffe SB,-Malpas JS. Male gonadal dysfunction in Hodgkin's disease. JAMA 1981;245: 1323-8.

' Waxman JHX, Terry YA, Wrigley PFM, et al. Gonadal function in Hodgkin's disease: long term follow-up of chemotherapy. Br Med J 1982;285: 1612-3.

${ }^{8}$ Chapman RH, Sutcliffe SB, Malpas JS. Male gonadal dysfunction in Hodgkin's disease. A prospective study. JAMA 1981;245: 1323-8.

" Vigersky RA, Chapman RM, Berenberg J, Glass AR. Testicular dysfunction in untreated Hodgkin's disease. Am J Med 1982;73:482-6.

${ }^{10}$ Chapman RM, Sutcliffe SB, Malpas JS. Cytotoxic-induced ovarian failure in women with Hodgkin's disease. I. Hormone function. JAMA 1978;242:1877-81.

"Chapman RM, Sutcliffe SB, Malpas JS. Cytotoxic-induced ovarian failure in Hodgkin's disease. II. Effects on sexual function. JAMA 1979;242:1882-4.

12 Shabar M, Klopper A. Plasma oestradiol and progesterone concentration in the normal menstrual cycle. Journal of Obstetrics and Gynaecology of the British Commonwealth 1973;80 :776-82.

${ }^{13}$ Hotchkiss L, Atkinson E, Knobil E. Time course of serum estrogen and luteinizing hormone concentrations during the menstrual cycle of the rhesus monkey. Endocrinology 1971;89:177-83.

14 Johannson EDB. Progesterone levels in the peripheral plesma during the luteal phase of the normal menstrual cycle measured by rapid competitive protein binding technique. Acta Endocrinol 1969;61:592-606.

is Furayama S, Mayes DM, Nugent CA. A radioimmunoassay for plasma testosterone. Steroids 1970;16:415-28.

${ }^{16}$ Chapman RM, Sutcliffe SB. Protection of ovarian function by oral contraceptives in women receiving chemotherapy for Hodgkin's disease. Blood 1981;58:848-51.

${ }^{17}$ Horning SJ, Hoppe RT, Kaplan HS, Rosenberg SA. Female reproductive potential after treatment for Hodgkin's disease. $N$ Engl J Med 1981;304:1377-81.

Requests for reprints to: Dr DJ King, Department of Medicine, Aberdeen Royal Infirmary, Foresterhill, Aberdeen AB9 2ZB, Scotland. 